\title{
The sun and fifteen doorways of Phnom Rung
}

\author{
Siramas Komonjinda ${ }^{1,2}$ \\ ${ }^{1}$ Department of Physics and Materials Science, Chiang Mai University, \\ Chiang Mai, Thailand \\ ${ }^{2}$ National Astronomical Research Institute of Thailand, \\ Chiang Mai, Thailand \\ email: siramas@gmail.com
}

\begin{abstract}
Phnom Rung was a Khmer-style Hindu temple complex. It was built in sandstone and laterite on the rim of an extinct volcano between the 10th and 13th centuries. At the beginning, the sanctuary was built as a dedication to Shiva. Following the abandonment of Phnom Rung (which was unrecorded) the sanctuary fell into ruin, and it was not until 1971 that it was restored using anastylosis. Phnom Rung Historical Park, along with the other temples Phimai and Muang Tum, have been on the tentative list for UNESCO World Heritage since 2004.

Walking from the eastern side (front) to the western side of Phnom Rung takes the visitor through 15 doorways - those of the inner cloisters, the annex, the principal tower, and the inner sanctum. The centers of these doorways are perfectly aligned, with an azimuth of $84.5^{\circ}$. Every year thousands of people from Thailand and around the world travel to Phnom Rung to see the sun rising through its all of its 15 doorways. This event happens only twice a year, at the beginning of April and the beginning of September. Sunsets can also be seen through the doorways, in March and October. Each pair of sunrise-sunset events is separated by one lunar month.

The possible meaning of this event has been investigated by both archaeologists and astronomers. Nothing is recorded about sunrise or sunset among the inscriptions at the site. Another issue is that the many and various structures remain within the complex, showing that constructions in this area spanned several centuries. However, it seems that the overall layout did have a significance, both astronomical and religious.
\end{abstract}

Keywords. history and philosophy of astronomy, Phnom Rung, Khmer temple complex, solar alignment

\section{History of Phnom Rung}

Phnom Rung Temple is a Khmer-style stone complex. It is situated at $14^{\circ} 31^{\prime} 53^{\prime \prime} \mathrm{N}$, $102^{\circ} 56^{\prime} 32^{\prime \prime} \mathrm{E}$ (M.2 Don Nong Hane, Ta Pek, Chalerm Phrakiat, Burirum province). The site is on a rim of an inactive volcano, at $383 \mathrm{~m}$ above sea level and $200 \mathrm{~m}$ above the surrounding plain. The mountain is of basalt while the surrounding area is sedimentary. The name of the mountain is Phnom Rung, following the name of the temple on the top Prasat Phnom Rung (PRĀSĀD BNAM RUNं). The meaning of this name has been discussed by many scholars, but a hypothesis that are widely accepted is that it simply means 'big-mountain stone temple' (Prasat $=$ Khmer stone temple, Phnom $=$ mountain, Rung = big).

Phnom Rung is believed to have been built during the 10th to 13th centuries (Subhadaradis Disakul 1974). At the beginning, the sandstone and laterite structure was a sanctuary dedicated to Shiva, who was believed to live in a palace on top of the mythical Krailasa Mountain. The temple faced east. 
There is no record of the abandonment of the sanctuary, which subsequently fell into ruin. However, folk tales continued to be told locally about its construction.

Prince Damrong Rajanubhab visited and explored the sanctuary in 1908 and in 1929. In 1935, the Fine Arts Department of Thailand declared the area an historical monument. The restoration of Phnom Rung was begun in 1971 using the anastylosis technique. The site was officially declared the Phnom Rung Historical Park in 1988.

Phnom Rung, together with two nearby Khmer temple complexes, Phimai and Muang Tum, have been on the tentative list for UNESCO World Heritage since 2004 and will soon be nominated for the UNESCO World Heritage List.

\section{The architecture of Phnom Rung}

The Phnom Rung complex covers an area of $0.2 \mathrm{~km}^{2}$. The main structure of the sanctuary extends from the eastern shoulder of the mountain upwards to the top of the hill (see Fig. 1).

The grand terrace step [1], Bundai Ton Thang, is composed of three laterite block steps that lead to a cross-shaped terrace. Fragments of roof tiles were found here. This may have been the base of a pavilion or an entrance gate.

On the northern side of the steps is a pavilion made of laterite [2]. This building may have been a place for the king to rest and change his attire upon arrival. This pavilion is sometimes called Roang Change Phuak, 'white elephant pavilion'.

There is a $160 \mathrm{~m}$-long stone-paved walkway [3] leading up the temple from the western side of the cross-shaped terrace. Columns with lotus-bud capitals, dating to the 12th century (Angkor Wat period), decorate both sides of this walkway. The columns are called Sao Nang Riang. They are symmetrically and evenly spaced along the two sides of the walkway.

At the end of this walkway is another cross-shaped terrace, Lower Naga Bridge [4]. This is a symbol linking this world and the celestial world, like a rainbow. One who crosses this bridge will be in a sacred place. After the Lower Naga Bridge are fifty-two stone steps up to a platform.

The Upper Naga Bridge [5] is in the middle of the platform that leads to the main entrance of the outer cloister. Both the Upper and Lower Naga Bridges have, in the

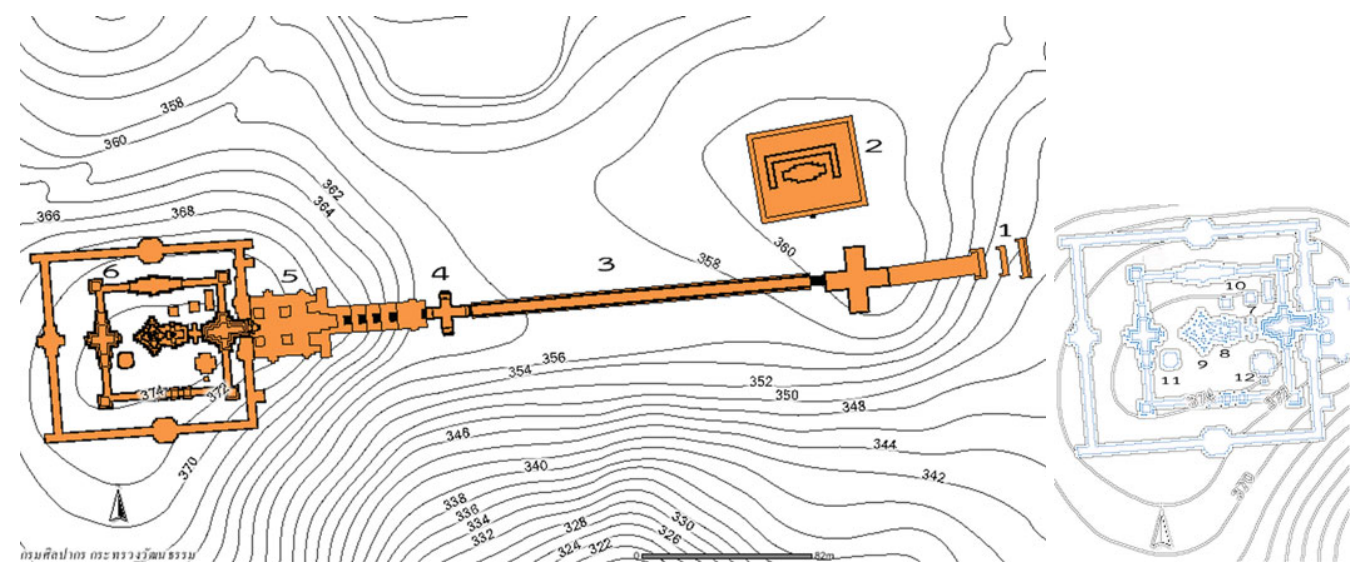

Figure 1. Plan of the Phnom Rung complex (left) and the area inside the inner cloister (right), adapted from the GIS map of the Fine Arts Department (adapted from http:// www.gis.finearts.go.th) 
middle, a large carving of a lotus in full bloom with eight petals, representing the guardian deities of the eight directions.

The Upper Naga Bridge is in a middle of the eastern side of a ruined outer cloister. Only parts of its base remain today. The inner cloister [6], however, can still be seen today. It is made entirely of sandstone except for the northern side, which is made of laterite. The length of the eastern and western sides of this cloister is $59 \mathrm{~m}$. At the center of each is a doorway, Gopura, decorated with fine carved stone open to the inner courtyard. The East Gopura enters onto the Small Naga Bridge [7] which connects to an annex in front of the principal tower. The northern and southern sides of the cloister have the same length: $68 \mathrm{~m}$. The northern side has two doorways while the southern side has three - two aligned with those on the other side, and an additional one. The decoration of this cloister is a mixture from several periods.

The annex, or mandapa [8], has a decorated entrance coming in from the east. This entrance has a step decorated with a lotus in bloom. Its pediment is superbly carved with a Dancing Shiva, suggesting that this temple was built as an offering to Shiva. At the center of the mandapa stands a large statue of a crouching Hindu cow.

The principal tower, or Prang [9] (Fig. 2), is decorated with magnificent stone carvings. These depict Hindu beliefs, with scenes from the Ramayana and Mahabharata, as well as ceremonies and events in daily life. The main part, Ruan That, is $27 \mathrm{~m}$ in height. It is designed with a room or inner sanctum, the Garbhagruha room, which enshrines the holy symbol of this temple, the Shiva Lingum. However, the symbol itself is missing. Judging from the decorations, carvings, and inscriptions Princess Maha Chakri Sirindhorn (1979) proposed that this principal tower was built during the Angkor Wat period.

The principal tower is not the only building in the inner courtyard: there are also buildings from different periods. These include two brick prangs [10] in the north-eastern
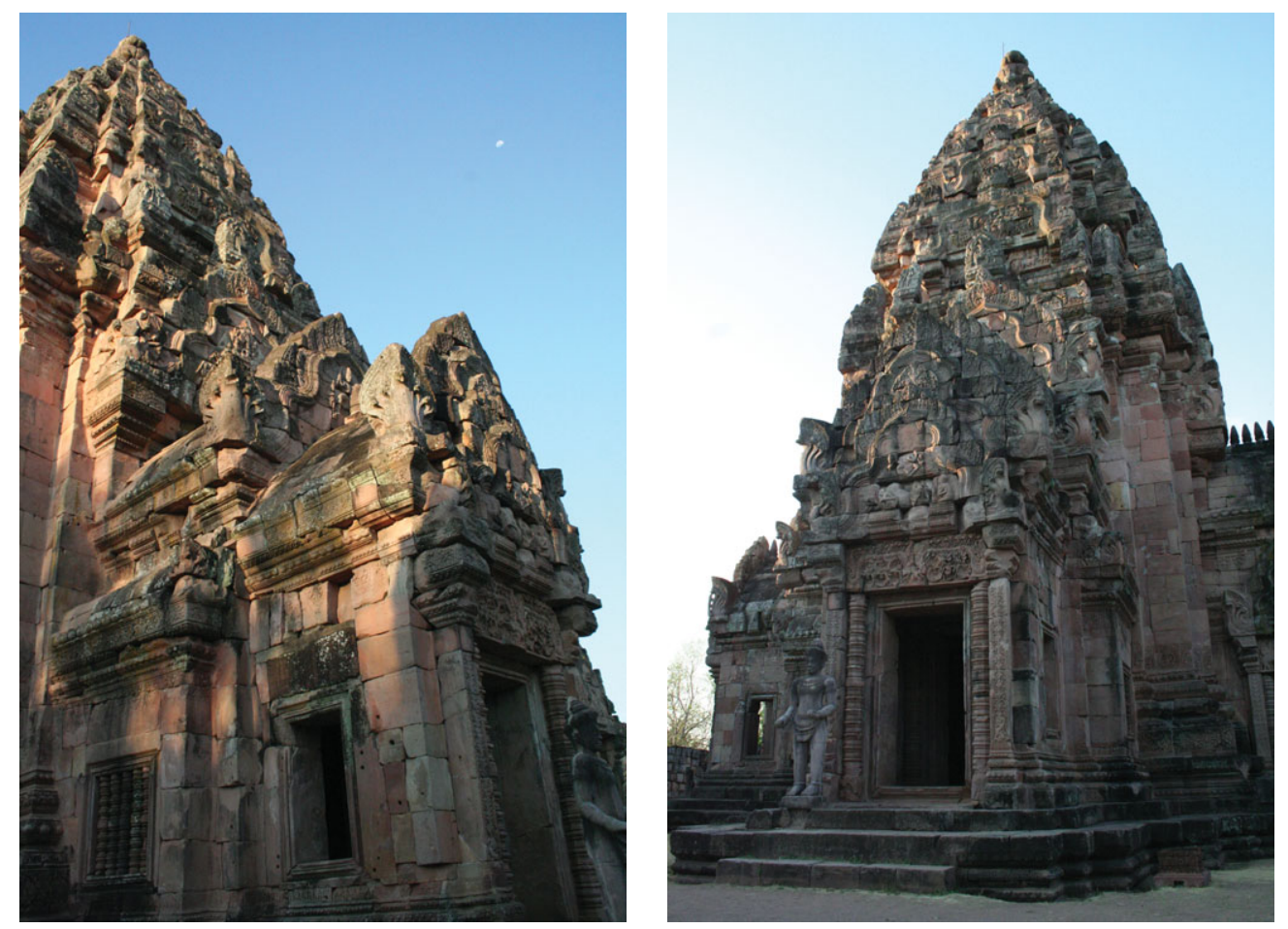

Figure 2. The principal tower: Left: the mandapa; Right: viewed from the south. 
part of the inner court. One faces east while the other faces south. These towers are the oldest constructions of Phnom Rung, being dated to the 10th century. Only part of them remains.

The small prang or Prang Noi [11]) is on the south-western side of the principal tower. The decoration on this building indicates that it was built around the 11 th century. The top part of this prang is damaged.

Two laterite buildings to the south-east and north-east of the principal tower are Bannalai, or libraries [12]. One faces west while the other faces south. This type of building was popular in the Bayon period (13th century).

\section{The sun phenomena at Phnom Rung}

The architecture of Phnom Rung means that someone walking from the eastern to the western side of the temple will pass through 15 doorways. They are those of the East Gopura, the inner cloister, the annex, the principal tower, and the inner sanctum. The centers of these doorways are perfectly aligned, with an azimuth of $84.5^{\circ}$.

On particular days, the sun shines into the inner sanctum, and quite possibly shone on to the lost Shiva Lingum (Figs $3 \& 4$ ). There is no record or folk story about this event: it was discovered accidentally by an archaeologist one morning after the restoration had been completed.

During the past few years, people have come to believe that this event happens on the morning after the night of the full moon in the fifth month of the Thai lunar calendar, which is approximately in April. They treat it as a miracle, related to the belief in Shiva. Thousands of people from Thailand and around the world now travel to Phnom Rung to see the run rising through its all 15 doorways and to celebrate the event.

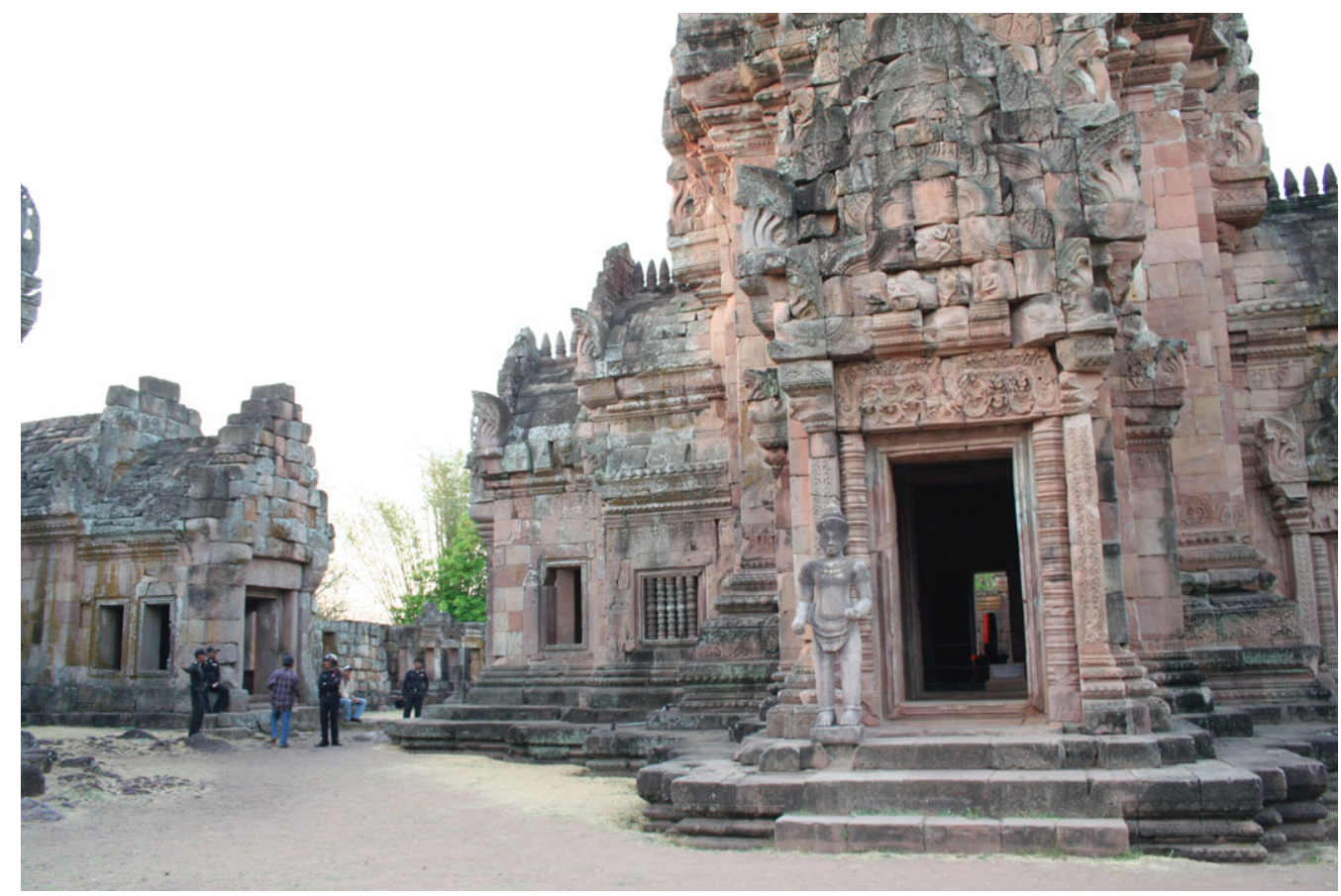

Figure 3. View towards the south entrance of the principal tower at the time of the sunset event in October 2009. 


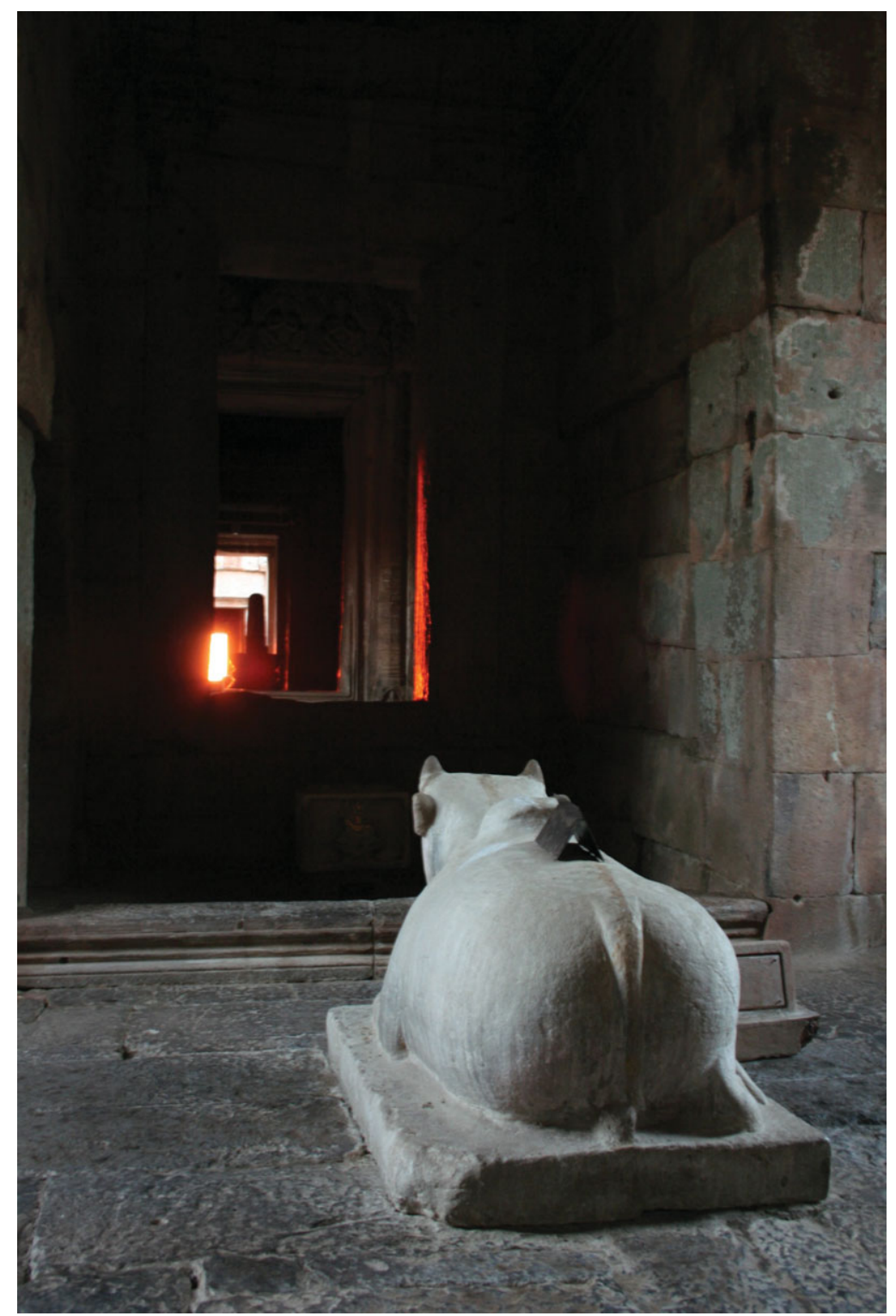

Figure 4. Photo taken at the time of the sunset event of October 2009 from the southern side of the inner court, inside the madapa behind the crouching cow.

As astronomers, we know that the event is related to the position of the sun, not to the moon. It happens four times a year: twice at sunrise, on $\sim 2-4$ April and $\sim 8-10$ September, and twice at sunset, on $\sim 5-7$ March and $\sim 5-7$ October. It does happen that each pair of sunrise-sunset events is separated by one lunar month. Some of the Khmer temples also incorporate an architectural alignment but not at $84.5^{\circ}$ as at Phnom Rung. This means that the separation of each pair of sunrise-sunset events is not separated by one lunar month.

Three Sanskrit and seven Khmer inscriptions were found at Phnom Rung. They were first translated by Coedés (1953). The full Thai translation was done by Sirindhorn (1979), and the latest translation into Thai is by Kunto (1982). Only one of these inscriptions says anything about the sunlight at this site. It is inscription K. 1069 (or Phnom Rung 9). 
Lines 18-19 of this inscription can be translated as

Kailasa, beautiful and delightful to worship full of beauty, balancing various kinds of beauty.

Shiva performs on the mid-sweep of the sun using the beauty of Kailasa, as in the past.

while lines 20-21 read

\author{
He, Shiva, is following Brahma Yoga \\ He sits for meditation in the morning. \\ Because he is afraid of breaking eggs, \\ he does Yoga gently with ghosts.
}

Loy Chunpongthong first calculated the exact time of the sunrise event in 1994, concluding that it was used as a tool to correct the lunar-solar calendar (priv. comm. 2010). Mollerup (2007) surveyed a number of prasat, Khmer stone temples, in Thailand close to the border with Laos and Cambodia and found that while nearly all of them have aligned doorways, only around $20 \%$ of them are similarly aligned to those at Phnom Rung. He concluded that the if the orientation of Prasat Phanom Rung did have an deliberate astronomical significance, then this would have been solar-lunar rather than just solar.

\title{
4. Conclusion
}

The meaning of the sunrise-sunset event through the doorways of Phnom Rung remains a mystery. More investigation is needed from the perspectives of history and religion as well as astronomy. Surveys of other Khmer temples are clearly needed for comparative purposes.

Despite the fact that the astronomical purpose of Phnom Rung is not yet understood, the National Astronomical Research Institute of Thailand has declared it to be an 'astronomical landmark of Thailand' and designated it a 'gateway to archaeoastronomy'.

\section{Acknowledgements}

The author would like to thank Mr Loy Chunpongthong and Mr Asger Mollerup for their work on Phnom Rung and for useful discussions. Thanks are also due to Dr Rungroj Phiromanukul and Mr Chaturaporn Tiamtinkrit for discussions on the archaeological view of the Phnom Rung event.

Thanks are also due to the Fine Arts Department, Ministry of Culture and Burirum Province for their help during the observation of the event. The work done at Phnom Rung was supported by the National Astronomical Research Institute of Thailand. Participation at the 'Oxford IX' International Symposium on Archaeoastronomy was supported by the International Astronomical Union and the National Astronomical Research Institute of Thailand.

\section{References}

Coedés, G. 1953, Inscriptions du Cambodge vol. V, Imprimerie d'Extrême-Orient, Hanoi.

Kunto, U. 1982, Sanskrit inscription of Phnom Rung, Fine Arts Department, Bangkok [in Thai]. Mollerup, A. 2007, Solar-lunar events at Prasat Phanom Rung in spring 2007 AD (2550 BE), Muang Boran Journal 33 (http://www.muangboranjournal.com/ modules $\cdot$ php?name=Sections\&op=viewarticle\&artid=163).

Sirindhorn, HRH Princess Maha Chakri 1978, The Inscriptions Found at PRA $\bar{A} \bar{A} D$ BNAM $R U \dot{N}$, Unpublished M.A. Thesis, Silpakorn University.

Subhadaradis Disakul, M. C. 1974, Age Determination of Phnom Rung, Fine Arts Department, Bangkok [in Thai]. 